\title{
Saharan dust transport and deposition towards the tropical northern Atlantic
}

\author{
K. Schepanski ${ }^{1,2}$, I. Tegen ${ }^{1}$, and A. Macke ${ }^{2}$ \\ ${ }^{1}$ Leibniz Institute for Tropospheric Research, Leipzig, Germany \\ ${ }^{2}$ Leibniz-Institute of Marine Sciences, IFM-GEOMAR, Kiel, Germany
}

Received: 17 June 2008 - Published in Atmos. Chem. Phys. Discuss.: 22 August 2008

Revised: 17 November 2008 - Accepted: 29 January 2009 - Published: 16 February 2009

\begin{abstract}
We present a study of Saharan dust export towards the tropical North Atlantic using the regional dust emission, transport and deposition model LM-MUSCAT. Horizontal and vertical distribution of dust optical thickness, concentration, and dry and wet deposition rates are used to describe seasonality of dust export and deposition towards the eastern Atlantic for three typical months in different seasons. Deposition rates strongly depend on the vertical dust distribution, which differs with seasons. Furthermore the contribution of dust originating from the Bodélé Depression to Saharan dust over the Atlantic is investigated. A maximum contribution of Bodélé dust transported towards the Cape Verde Islands is evident in winter when the Bodélé source area is most active and dominant with regard to activation frequency and dust emission. Limitations of using satellite retrievals to estimate dust deposition are highlighted.
\end{abstract}

\section{Introduction}

The Sahara as the World's most important dust source adjoins directly to the Atlantic ocean (e.g. Prospero et al., 2002; Middleton and Goudie, 2001; Goudie and Middleton, 2001; Washington et al., 2003). A major part of the Saharan mineral dust is exported towards the northern tropical Atlantic (e.g. Romero et al., 1999). Mineral dust consists of small soil particles with regionally specific mineralogical, chemical, physical, and optical properties. Besides the interactions with solar and thermal radiation as well as clouds during transport, mineral dust deposited onto soil or ocean surfaces acts as nutrient for terrestrial and oceanic ecosys-

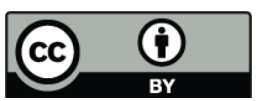

Correspondence to: K. Schepanski (kerstin.schepanski@tropos.de) tems (e.g. Mahowald et al., 2005). The bio-availability of micro-nutrients in mineral dust particles depends on their mineralogical and chemical properties that depend on source area mineralogy, and processes on the particle surfaces during transport in dry or aqueous phases (Goudie and Middleton, 2001; Luo et al., 2003; Journet et al., 2008). The Earth's surface contains around 4\% of iron (Wedepohl, 1995) and consequently soil-derived mineral dust can be considered as transport medium for iron from soil surface into ocean regions (Fung et al., 2000; Sarthou et al., 2003; Jickells et al., 2005). Iron in its role as micro-nutrient for ocean-ecosystems acts as controlling factor for life in high-nitrate, low chlorophyll (HNLC) regions, e.g. for phytoplankton growth (Neuer et al., 2004; Mahowald et al., 2005; Moore et al., 2006; Sarthou et al., 2007). In the tropical Atlantic, iron delivered by dust particles may enhance nitrogen fixation. By these processes dust deposition may be coupled to the $\mathrm{CO}_{2}$ budget and climate system (Gao et al., 2001 and references therein).

Remote sensing retrievals have been used to determine dust fluxes into the North Atlantic, assuming that the ratio of atmospheric dust load within a column and the corresponding aerosol optical thickness (AOT) can be described by a fixed value (e.g. Kaufman et al., 2005). Based on such analyses of satellite retrievals, the Bodélé Depression was claimed to be the major source for dust transport to the Amazon (Koren et al., 2006).

Oceanic dust deposition has also been estimated from global dust models (e.g. Zender and Newman, 2003; Mahowald et al., 2005). Regional models are suitable to investigate dust conditions for specific meteorological situations and are expected to provide better vertical resolution of dust layers compared to global-scale models, which is an important control of dust deposition.

Published by Copernicus Publications on behalf of the European Geosciences Union. 
This paper aims to show for three case studies the characteristics as well as the differences of dust transport concerning e.g. direction, height, and amount, and dust deposition towards the eastern tropical North Atlantic in different seasons. The contribution of dust emitted over the Bodélé Depression to the total exported Saharan dust will be estimated. Furthermore the relation of AOT of dust (in the following referred to as AOT) and atmospheric dust column load and deposition fluxes is discussed. This addresses the question whether it is possible to determine dust deposition from AOTs retrievals based on space-borne measurements provided by e.g. MODIS or SeaWiFS.

\section{Regional model system LM-MUSCAT}

To characterise Saharan dust transport and deposition towards the tropical North Atlantic, we use the dust transport model system LM-MUSCAT (Heinold et al., 2007). It consists of the regional scale meteorological model LM (provided by the Deutscher Wetterdienst, Steppler et al., 2003) and the MUlti-Scale Chemical Aerosol Transport Model (MUSCAT, Wolke et al., 2004a,b). The dust transport model includes a dust emission scheme based on Tegen et al. (2002). Meteorological and hydrological fields used for the simulation of dust emission, transport and deposition, are computed by the LM and updated in MUSCAT at every advection time step chosen to be $80 \mathrm{~s}$. Local wind systems, clouds, precipitation, and meso-scale convection depend on topography. For simulation of sub-grid scale moist convection the parameterisation following Tiedtke (1989) is used in the LM. Dust emission is modified by surface properties like vegetation, surface roughness, soil texture and soil moisture content. In addition to soil properties, wind shear stress at the ground is the major limiting factor for soil erosion. The wind shear stress $\tau$ is related to the air density $\rho_{a}$ and the friction velocity $u_{*}$, by $\tau=\rho_{a} u_{*}^{2}$. Dust emission occurs if the friction velocity exceeds a local, soil-dependent threshold $u_{* t}$ for dust mobilisation. Surface roughness elements like rocks and stones but also vegetation and the soil texture impact on the required momentum to mobilise soil particles. Here a parametrisation for $u_{* t}$ based on Iversen and White (1982) is used, modified by Marticorena and Bergametti (1995). The simulation of dust emission is allowed for areas, which have been observed to be dust sources at least two times during 03/2006-02/2007 using Meteosat Second Generation (MSG) infra-red dust index imagery (Schepanski et al., 2007). The size distribution of particles during emission depends on the actual wind velocity and local soil characteristics (Tegen et al., 2006).

Airborne dust is transported as passive tracer in five independent size bins (radius limits at: $0.1 \mu \mathrm{m}, 0.3 \mu \mathrm{m}, 0.9 \mu \mathrm{m}$, $2.6 \mu \mathrm{m}, 8 \mu \mathrm{m}$ and $24 \mu \mathrm{m}$ ). For each size bin spherical dust particles following a log-normal size distribution are assumed. Dust deposition is parametrised as dry and wet de- position. The parametrisation of dry deposition depends on particle size, density and meteorological conditions affecting the behaviour of dust particles. In detail the parametrisation considers turbulent transfer, Brownian diffusion, impaction, interception, gravitational settling, and particle rebound (Heinold et al., 2007). Dry deposition of dust particles is controlled mainly by gravitational settling, which is dominant for particles larger than $2 \mu \mathrm{m}$, and the impact of aerodynamic $\left(R_{a}\right)$ and surface resistance $\left(R_{s}\right)$. Gravitational settling, commonly described by the gravitational settling velocity $v_{d}$ is based on the Stoke's equation describing the equilibrium of gravitation and buoyancy:

$v_{g}=\frac{\left(\rho_{p}-\rho_{a}\right) g D_{p}^{2} C_{c}}{18 v}$

with particle diameter $D_{p}$, air density $\rho_{a}$, particle density $\rho_{p}=2.65 \mathrm{~g} / \mathrm{cm}^{3}$, the gravitational constant $\mathrm{g}$, the dynamic viscosity of air $v$, and the Cunningham correction factor $C_{c}$. The Cunningham correction takes into account that the Stoke's law considers the velocity of the air surrounding the particle's surface relative to the particle itself as zero. This assumption is correct in continuum but not for particle larger than the mean free path $\lambda$ of air molecules. The Cunningham correction factor $C_{c}$ is used to take this into account and is described by

$C_{c}=1+\frac{2 \lambda}{D_{p}}\left[1.142+0.558 \exp \left(-\frac{0.4995 D_{p}}{\lambda}\right)\right]$.

For particles smaller than $2 \mu \mathrm{m}$, the gravitational settling velocity $v_{g}$ is adjusted by the aerodynamic and surface resistance $R_{a}$ and $R_{S}$ to account for turbulent mix-out:

$v_{d}=\frac{1}{R_{a}+R_{s}+R_{a} R_{s} v_{g}}+v_{g}$.

Beside dry deposition, especially over the North Atlantic, wet deposition, e.g. by rain-out, has a strong influence on particle removal. In MUSCAT, the parametrisation follows Berge (1997) and Jacobson et al. (1997) and bases on the parametrisation used in the EMEP MSC-W Eulerian model by Tsyro and Erdman (2000). Wet deposition is controlled by the precipitation rate $p$ and the scavenging coefficient $\lambda$,

Dep_rate $=-\lambda \cdot p$,

with

$\lambda=\frac{A \cdot E}{v_{d r}}$,

related to an empirical coefficient $A=5.2 \mathrm{~m}^{3} / \mathrm{kg}$ s due to Marshall-Palmer size distribution assumed for rain drops, to the mean collection efficiency $E$, averaged over all rain drop sizes and to the rain drop fall velocity $v_{d r}$, here $v_{d r}=5 \mathrm{~m} / \mathrm{s}$.

For the computation of AOT at $550 \mathrm{~nm}$, dust concentrations of the five size bins (dust mode, $j$ ) are used. The dust 
particles are assumed to be spherical particles with a density of quartz $\left(\rho_{p}=2.65 \mathrm{~g} / \mathrm{cm}^{3}\right)$ :

$\tau=\sum_{j} \sum_{k}\left(\frac{3}{4} \frac{Q_{\mathrm{ext}, 550}(j)}{r_{\mathrm{eff}}(j) \rho_{p}(j)} c_{\mathrm{dust}}(j, k) \Delta z(k)\right)$

with the extinction efficiency $Q_{\text {ext }, 550}=$ (1.677, 3.179, 2.356, 2.144, 2.071, 2.034, 2.016, 2.008)

for each size bin (derived from Mie-theory, following Sinyuk et al., 2003), effective radius of dust particle $r_{\mathrm{eff}}(j)$, dust concentration $c_{\text {dust }}(j, k)$ at vertical level $k$, and the vertical increment of each vertical level $\Delta z(k)$. In the calculation of AOT from the model size distribution and refractive index information we use Mie-theory, i.e. a spherical shape of the dust particle is assumed, whereas the AERONET retrieval takes spheroidal dust particle shapes into account. However, our simplification only affects the calculation of the extinction efficiency, which is not very sensitive to particle shape at the dust size parameters in the solar spectral range.

For this study of dust transport and deposition towards the tropical North Atlantic, we run the model system on a $28 \mathrm{~km}$ horizontal grid resolution and $40 \sigma-p$ levels up to $12 \mathrm{~km}$ height, whereby the LM itself simulates the atmosphere up to $24 \mathrm{~km}$. The first level is centred around $38 \mathrm{~m}$ above ground level (agl). There is a spin-up period of $24 \mathrm{~h}$ for the LM part, after this period the MUSCAT is coupled to the LM. Every 6 hours, meteorological boundary conditions are updated with analysis fields from GME (global weather forecast model of the DWD). After $24 \mathrm{~h}$ of LM-MUSCAT computations, the meteorological fields are reinitialised. Three case studies of one month periods, in different seasons have been computed: March 2006, July 2006 and 20 December 2006 to 20 January 2007 (hereafter referred to as January 2007).

\section{Dust transport and deposition towards the tropical North Atlantic}

The Sahara and Sahel region over North Africa contains several potential dust source areas, mostly located in the foothills of the mountain areas where endorheic drainage systems (systems formed by flowing water), and wadis opening to fluvial fans provide a large amount of sediment available for aeolian erosion (e.g. Washington et al., 2003; Schepanski et al., 2007). Each dust source area is characterised by seasonal and annual changes in frequency of dust source activation (Schepanski et al., 2008). Consequently, seasonal changes in spatio-temporal dust source activity are related to seasonal changes in local meteorological conditions providing atmospheric conditions for dust mobilisation. Here, potential dust emission areas are limited to areas which have been observed to be dust sources (Schepanski et al., 2007). Seasonal changes in active dust source areas are not prescribed as the simulated atmospheric conditions should be able to reproduce seasonal changing conditions fulfilling and inhibiting dust emission, respectively. However, as local meteorological conditions are influenced by regional and mesoscale meteorological systems, dust transport is affected regarding amount, height of transport layer, and dry and wet deposition rates respectively.

To investigate typical transport and deposition patterns of Saharan dust in different seasons, three modelling studies for one month periods (March 2006, July 2006 and January 2007) representing different seasons (north hemispheric spring, summer and winter) have been performed using the regional model system LM-MUSCAT.

\subsection{Characteristics of Saharan dust transport}

To describe the horizontal distribution of atmospheric dust load, we have to distinguish between near-source area, areas affected by dust transport over the African continent and over the ocean. The atmospheric dust concentration over the near source area is mainly characterised by the dust source activity, the wind direction and speed, and atmospheric stability (Kalu, 1979). The dust particle sizes are larger close to the source region and decrease with distance due to gravitational settling (e.g. Westphal et al., 1987). Dust is mixed up by turbulent mixing within the boundary layer (BL), transported within the regional wind flow or removed from the atmosphere by either dry or wet deposition. During transport, the dust plume can remain near the surface and be observed as dust storm, or can be transported as elevated layer. Within the daytime BL, dust concentration can be homogeneously distributed over the entire BL depth (Tesche et al., 2009). In the evening, mixing activity within the BL ceases and a significantly shallower nocturnal BL remains (Garratt, 1992). However, airborne dust can be still present in the residual layer. During night, the air layer does not change its height and will be re-mixed to the developing daytime BL (Blackadar, 1957; Lenschow and Stankov, 1979; Kalu, 1979). Alternatively, air masses above the nocturnal BL can be accelerated due to geostrophy caused by pressure gradient forces between the Saharan heat low and the surrounding higher air pressure and the Coriolis force. During day time, surface friction decelerates geostrophic air flows to sub-geostrophic wind velocities. During night, surface friction does not act on the air flow at levels above the decoupling inversion on top of the shallower nocturnal BL and the wind accelerates. As the BL depth shrinks relatively fast after sunset, the geostrophic equilibrium over-accelerates the wind flow to super-geostrophic wind velocities and a wind speed maximum develops, also termed as nocturnal low-level jet (LLJ) (e.g. Nappo, 1991; Banta et al., 2006; Schepanski et al., 2008). So the elevated air mass with its dust content is transported relatively fast away from the source area (Kalu, 1979; Westphal et al., 1987). Transported dust layers during night within a low-level jet might be mixed into the developing BL the next day and might lead to decreasing horizontal 

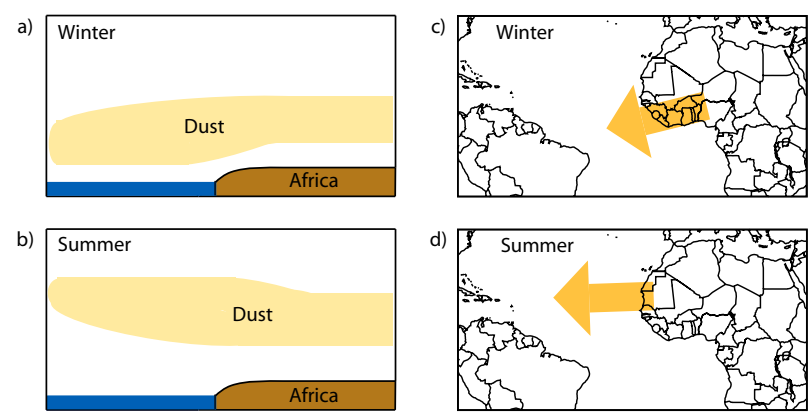

Fig. 1. Schematic diagram of vertical and horizontal dust export from North Africa towards the tropical East Atlantic for Northern Hemisphere winter (a, c) and summer (b, d). After Kalu (1979).

visibilities, which have been observed during the build-up phase of the daytime BL (Kalu, 1979).

Atmospheric dust layers that are transported away from the sources can be elevated to higher levels compared to dust near its source. The elevation of dust layers depends on the season (see Fig. 1).

During winter, the dust layers over the West African continent are situated at lower levels than during summer (Kalu, 1979). In winter months, transported Saharan dust is observed at near-surface layers, while in summer the dust layer is elevated. This is due to seasonally different meteorological regimes especially over the Sahel and the Western Sahara. Due to northward shift of the ITD (inner-tropical discontinuity, marking the meeting of dusty desert air and tropical moist air) and higher insolation leading to a larger surface heating the BL is deeper during summer which results in a higher upward-mixing of dust. During night the West African Monsoon (WAM) circulation forces the development of high geostrophic wind speeds in the decoupled, elevated air layer (e.g. Parker et al., 2005). Dust can be mixed up high into troposphere and be transported rapidly during night. Additionally, dust layers within the mid-troposphere overlay the moist and denser monsoon air and reaches higher transport levels in summer than in winter when the dust layer is transported within the trade winds (Kalu, 1979). The location of the ITD is father south in winter, so the high vertical mixing of dusty air occurs further south over the South Sahel. In summer this strong mixing occurs further north over the Sahel/South Sahara due to northward shift of the Hadley circulation. Over the ocean, the Saharan dust layer is transported above the trade winds inversion (up to 5-7 km above sea level) (Kalu, 1979, Chiapello et al., 1997; Dunion and Velden, 2004; Karyampudi et al., 1999) in north hemispheric summer (Fig. 1). In winter the dust is transported within the trade wind layer at altitudes below 1.5-3 km (Chiapello et al., 1997; Barkan et al., 2004).

\subsection{Horizontal distribution of AOT}

Horizontal dust transport paths can be tracked considering the distribution of AOT, e.g. provided for remote areas by satellite products (Fig. 2). Furthermore, satellite products are often used and are well suitable for model validation as they provide information on a larger spatial scale compared to station measurements. Several satellite products from different instruments are available, e.g. MODIS (MOderate resolution Imaging Spectrometer) on-board the polar orbiting satellites Aqua and Terra and OMI (Ozone Monitoring Instrument) on-board the Aura satellite. Here, three satellite products applied to measurements at different ranges of wavelength provided by those satellite platforms are used to validate the model's ability to reproduce horizontal aerosol distribution on a monthly time scale. For MODIS, two AOT products are available: MODIS AOT applied to measurements at visible wavelength and DeepBlue AOT (Hsu et al., 2004) applied to the deep-blue part of the visible spectrum. The MODIS AOT product is limited to dark surfaces like the Ocean or high vegetated land surfaces. Here it is used to validate the monthly mean AOT values over the Atlantic. The usage of measurements at deep-blue wavelengths $(412 \mathrm{~nm}, 490 \mathrm{~nm}$ and $670 \mathrm{~nm}$ ) situated in the high-frequency part of the visible spectrum allow AOT retrieval over bright surfaces due to low surface reflectance at this part of the spectrum. DeepBlue AOT is used here to validate monthly mean AOT over land surfaces. Both AOT retrievals do not only consider dust, also aerosol particles like sea-salt and soot add to the AOT values. The third index used here for validation aspects is the OMI Absorbing Aerosol Index (AI, Herman et al., 1997). This index is applied to measurements at ultra-violet (UV) wavelength. At UV wavelength the surface reflectivity is low (Eck et al., 1987) and so UV absorbing aerosol like mineral dust (and also biomass burning aerosol) can be detected due to spectral different back-scattering effects (Veihelmann et al., 2007). The AI provides a qualitative indicator for the presence of dust. Compared to AOT retrievals, the AI values are not affected by the presence of sea-salt particles (Torres et al., 2002). The AI values are sensitive to the height of the aerosol layer (Israelevich et al., 2002).

Figure 2 shows monthly means of three different aerosol products in comparison to the modelled dust distribution for the same time period based on noon-time AOT values. Missing values (e.g. due to clouds) for the satellite products are taken into account. Depending on the wavelengths to which the retrieval algorithm is applied, information on the atmospheric dust content indicated by AOT and AI, respectively, are available for different underlying surfaces. The comparison highlights that retrievals applied to different wavelengths may show different features in terms of high index values. For July 2006, the OMI AI indicate high mean index values over Mali and Mauritania, the DeepBlue AOT shows a maximum pattern over the Bodélé Depression area. Different retrievals show different sensitivities concerning e.g. particle 

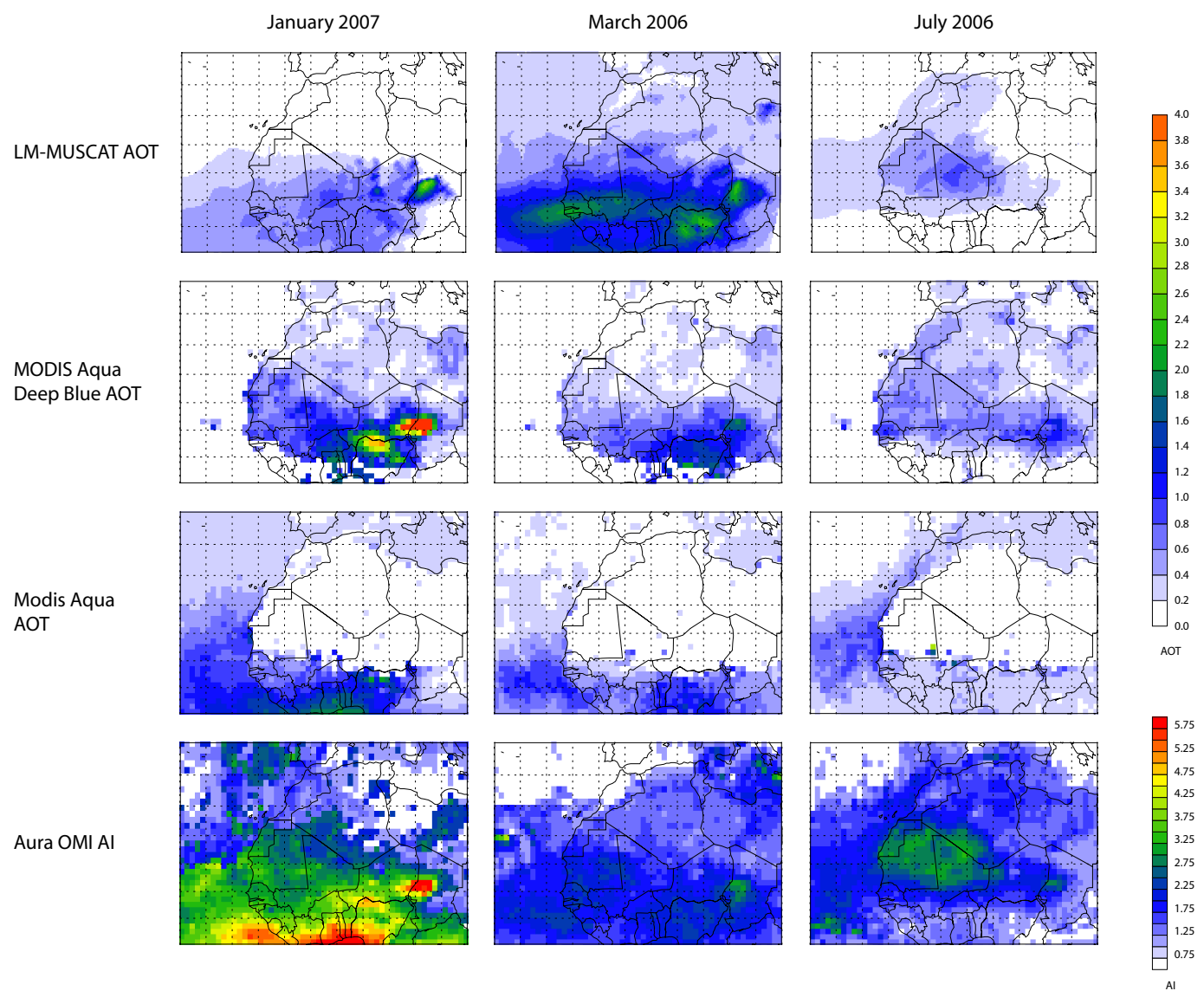

Fig. 2. Monthly mean AOT retrieved from model simulations and satellite observations done by MODIS and OMI instruments for January 2007, March 2006 and July 2006. Differences are due to model shortcomings and the sensitivities of the satellite retrievals. OMI AI values give a semi-quantitative information on atmospheric dust content.

characteristics, which have to be considered. Furthermore, the AI detects aerosol due to biomass burning as well as dust which becomes important especially in boreal winter. Soot contributes to the maximum AI pattern shown in Fig. 2 for January 2007, which is also true for MODIS AOT and DeepBlue AOT. As the model only accounts for mineral dust aerosol, no other aerosol types contribute to the model based AOT. Remote sensing products for mineral dust are used to validate the horizontal distribution of simulated dust. For January, high AOT values are simulated over the Bodélé Depression, Niger and western Mali by LM-MUSCAT. The plume spread out in westward direction with an axis which can be drawn crossing Mali and Guinea. Similar patterns are evident in the remote sensing products. The MODIS AOT product shows a similar northward extent of the dust plume over the Atlantic, but with slightly higher AOT values compared to the model. This is especially evident over the tropical Ocean, where the contribution of biomass burning aerosol increases the observed AOT. OMI AI shows similar pattern of airborne dust distribution. Over land surfaces, the AOT patterns of the model simulation agree in general with the remotely sensed patterns, but they disagree in detail: The maximum mean AOT values simulated over the Bodélé Depression is around 2.8, measurement retrievals indicate AOTs up to 5 by the DeepBlue product. Furthermore, the satellite products point towards a second aerosol hot spot north of the Highlands of Jos (Nigeria) which is not represented in the model mean values, but may be due to biomass burning aerosol. Also, over the continent the simulated AOT values are slightly lower compared to the satellite retrieval. The horizontal distribution of simulated mean AOT for March 2006 agrees well compared to the satellite retrievals. The position of the dust plume entering towards the tropical Atlantic agrees well in LM-MUSCAT simulations and MODIS AOT retrievals, whereby in March the modelled AOT values are higher than AOT from remote sensing. LM-MUSCAT AOT, OMI AI and DeepBlue AOT, agree well regarding pattern distribution, but also over land the simulated AOT values are higher than the retrieval. The summer case (July 2006) agrees well concerning the range of mean AOT values over 

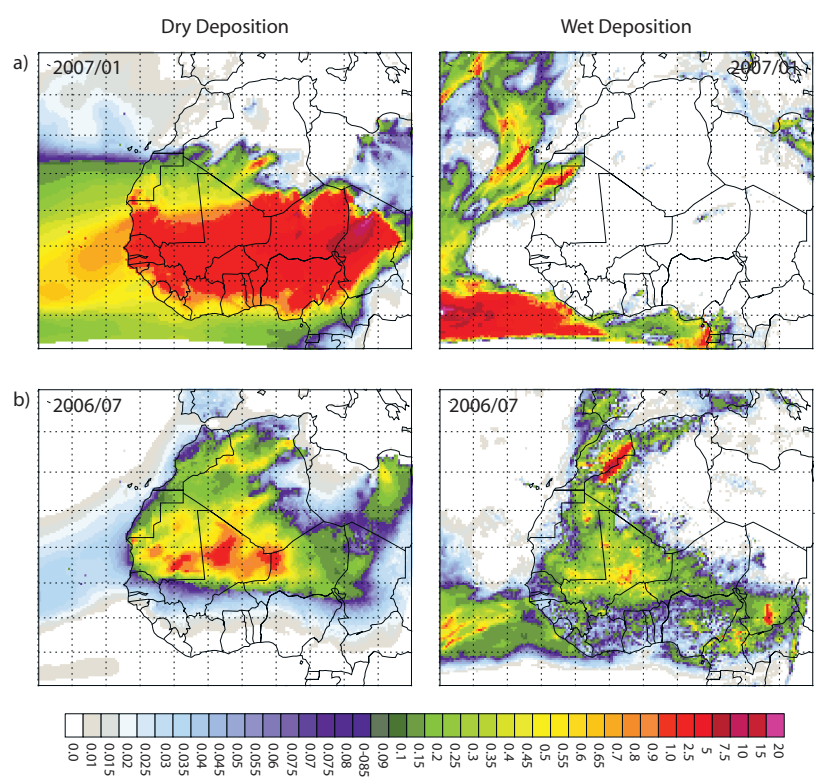

$\left[\mathrm{g} / \mathrm{m}^{2} / \mathrm{month}\right]$

Fig. 3. Monthly dust dry and wet deposition fluxes for January 2007 (a) and July 2006 (b), computed by the regional model LMMUSCAT.

the continent, but again some differences are evident regarding the location of hot spot patterns: The simulations show a maximum mean AOT located over central Mali in agreement with OMI AI whereby the AI maximum is shifted to the west. DeepBlue AOT pattern indicate higher values over this areas, but show a maximum over the Bodélé which is not represented by the model. Outside of "hot spot" areas the OMI $\mathrm{AI}$ and DeepBlue AOT show similar patterns. In summary, monthly mean AOT distributions are in good agreement with satellite AOT retrievals concerning their horizontal patterns and the range of values. The model simulated AOTs over the Atlantic are lower compared to the satellite data in summer.

The atmospheric dust content is a result of dust emission, transport and deposition. So the comparison of horizontal distribution of dust load, here indicated by the AOT, shows implicitly the accuracy of the treatment of dust emission, transport and deposition, each requiring a correct reproduction of meteorological conditions. To account for the importance of accurate treatment of the meteorological conditions for this regional model system, especially the wind distribution as limiting factor for dust emission, we refer to the studies of Heinold et al. (2007); Laurent et al. (2008) and Reinfried et al. (2008). Furthermore, Schepanski et al. (2008) investigate the ability of LM-MUSCAT to reproduce the occurrence of nocturnal LLJs, which has been identified to be an important feature for Saharan dust mobilisation.

Besides the validation of the model's horizontal distribution of atmospheric dust loads, seasonal characteristics of extent and strength of North African dust plumes are evident.
In summer, transport direction of the main plume is in westward direction, in winter its direction is in southwestward direction, which is in agreement with long-term observations (e.g. Romero et al., 1999).

\subsection{Monthly distribution of dry and wet dust deposition}

Airborne dust can be removed from the atmosphere by dry or wet deposition. Deposition measurements are sparse, so here the discussion bases on the assumption that a reliable field of AOT implicitly includes a correct treatment of deposition fluxes. The reliability of the model's dust fields are validated using horizontal distributions of monthly mean AOTs (Sect. 3.2), temporal evolution of single dust plumes at measurement sites provided by AERONET (Sect. 3.4) and the particle size distribution observed at these stations (Sect. 3.5).

The relative importance of dry or wet deposition processes differs regionally and changes with seasons (Fig. 3). During winter (January 2007, Fig. 3a), wet deposition is negligible over nearly the entire North African domain, while dry deposition is very dominant and represents the pattern of mean AOT. High dry deposition rates over Tunisia, the western foothills of the Hoggar Massif and western Algeria in the presence of relative low mean AOT values (Fig. 2) indicate near-source deposition and short residence time of dust within the atmosphere. Wet deposition occurs mainly over the Atlantic related to moist convection within the tropical convergence zone and low pressure disturbances further north. Over the tropical East Atlantic, the Saharan air layer (SAL), a very dry, warm and dusty air mass originating from the desert, is characterised by negligible wet deposition (lower than $0.01 \mathrm{~g} / \mathrm{m}^{2}$ month), high dry deposition (up to $1 \mathrm{~g} / \mathrm{m}^{2}$ month) rates compared to other Atlantic regions and high mean AOT (Figs. 2 and 3). During March 2006 (not shown) representing a spring month, the same features as described for January 2007 can be found. The domain of high dry deposition rates and negligible wet deposition rates is centred further north due to northward shift of Hadley circulation. In summer, moist convection occurs especially over the mountains and the monsoon region. Thus wet deposition occurs especially over the West Sahara, the Sahel and the Atlas Mountains. Dominance of wet deposition is indicated by high deposition rates (up to $10 \mathrm{~g} / \mathrm{m}^{2}$ month over the Atlas and up to $5 \mathrm{~g} / \mathrm{m}^{2}$ month over the West Sahara) in these areas. High dry deposition rates are also found over the West and Central Sahara (up to $10 \mathrm{~g} / \mathrm{m}^{2}$ month). The coincidence of both, dry and wet deposition in this region characterise summer months and point towards the varying weather character of the monsoon period.

In summer, the dusty Saharan air is elevated above the marine boundary layer and the dust concentration at nearsurface levels decreases (e.g. Karyampudi et al., 1999). Fields of dry deposition simulated by LM-MUSCAT indicate an elevation of the Saharan dust layer and thereby a decrease 
of dust load at the lowest level as shown for the Cape Verde Islands in Fig. 4, but a too strong decrease of total deposition fluxes is evident following the shape of the coastline. This effect causes also the lower AOT compared to DeepBlue and will be investigated in future studies.

\subsection{Temporal evolution of the dust concentration}

Beside the horizontal distribution of the atmospheric dust load (shown as monthly mean values, Fig. 2), the temporal evolution of AOT values is compared. Sun-photometer measurements performed in the framework of AERONET (AErosol RObotic NETwork, Holben et al., 1998) are used to characterise the temporal evolution of dust plumes for measurement sites located in North Africa.

Dust emission does not occur continuously in space and time. The spatial distribution of active dust sources changes within the day, from day to day and season to season (Schepanski et al., 2007). In remote areas where the dust transport is affected by the atmospheric flow pattern, the pulsed characteristic of dust emission is smoothed depending on atmospheric situation (e.g. clouds, precipitation) during transport. Cloud-free level-2 AOT sun-photometer measurements at AERONET sites located more closely to source areas and those located in the far-field dust transport path are chosen to evaluate the simulated dust export to the Atlantic ocean at different seasons (Fig. 5). The AOT measurements do not distinguish between aerosol types like mineral dust and soot, but consider a mixture of spherical and non-spherical components (Dubovik et al., 2006). Over the Sahel and tropical North Africa the contribution of soot to the measured AOT might be high, especially in winter when biomass burning is a frequent phenomenon over this area. To ensure that the fraction of dust to the measured AOT is the dominant, only those AOT retrievals are considered, where the AOT $\geq 0.3$ and the Angström coefficient $\alpha \leq 0.6$ following Dubovik et al. (2002). The sites are chosen with regard to obtain an overview of Saharan dust export at different latitudes.

During March 2006, an extra-ordinary dust storm occurred (Tulet et al., 2008) starting on March 2005 in the Atlas Mountains initiated by a upper-level trough and crossing southward to the Sahel and the tropical Atlantic ocean. This strong event is dominant at all sites located in the remote transport path. At Tamanrasset this event is not evident as this site is not situated in the dust transport path. Comparing AOT measurements to the model simulation, the character of the month is well reproduced, but the strength of the extraordinary event during the beginning of the month is overestimated by the model at all stations.

In July 2006, the range of observed and simulated AOT values is significantly lower than during spring (March 2006). The temporal evolution of dust plumes is well represented regarding onset and AOT range for Tenerife over the whole month. At most other stations, crossing dust plumes
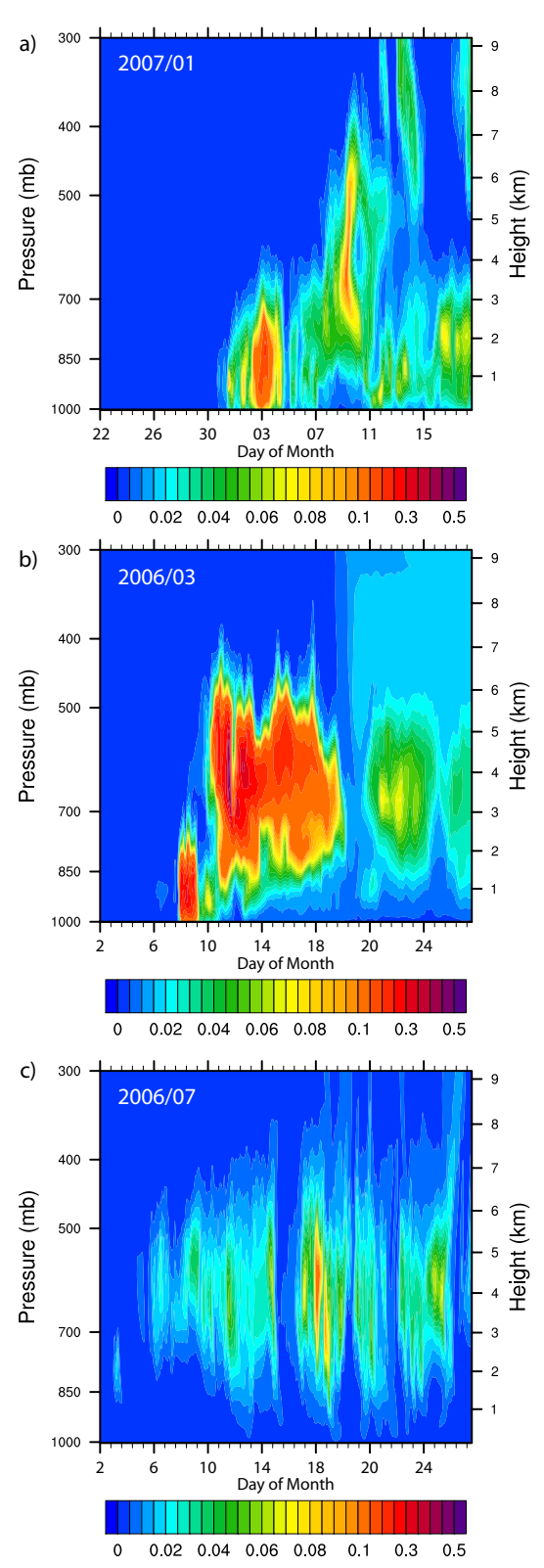

Fig. 4. Temporal evolution of the vertical dust concentration $\left[\mathrm{g} / \mathrm{cm}^{3}\right]$ distribution over Sal, Cape Verde $\left(16^{\circ} \mathrm{N} ; 22^{\circ} \mathrm{W}\right)$ for January 2007 (a), March 2006 (b) and July 2006 (c).

during the first half of the month are underestimated by the model, but in general representing the onset and offset of observed dust plumes. During the second half of the month, dust occurrence is well represented regarding the strength of the dust plume and its temporal evolution.

January 2007 shows similar characteristics as March 2006. The range of observed and modelled AOT values is higher than during summer, which is also evident in seasonal differences shown in Fig. 2. The characteristics of the AOT evolution is well represented at all stations, but the second 

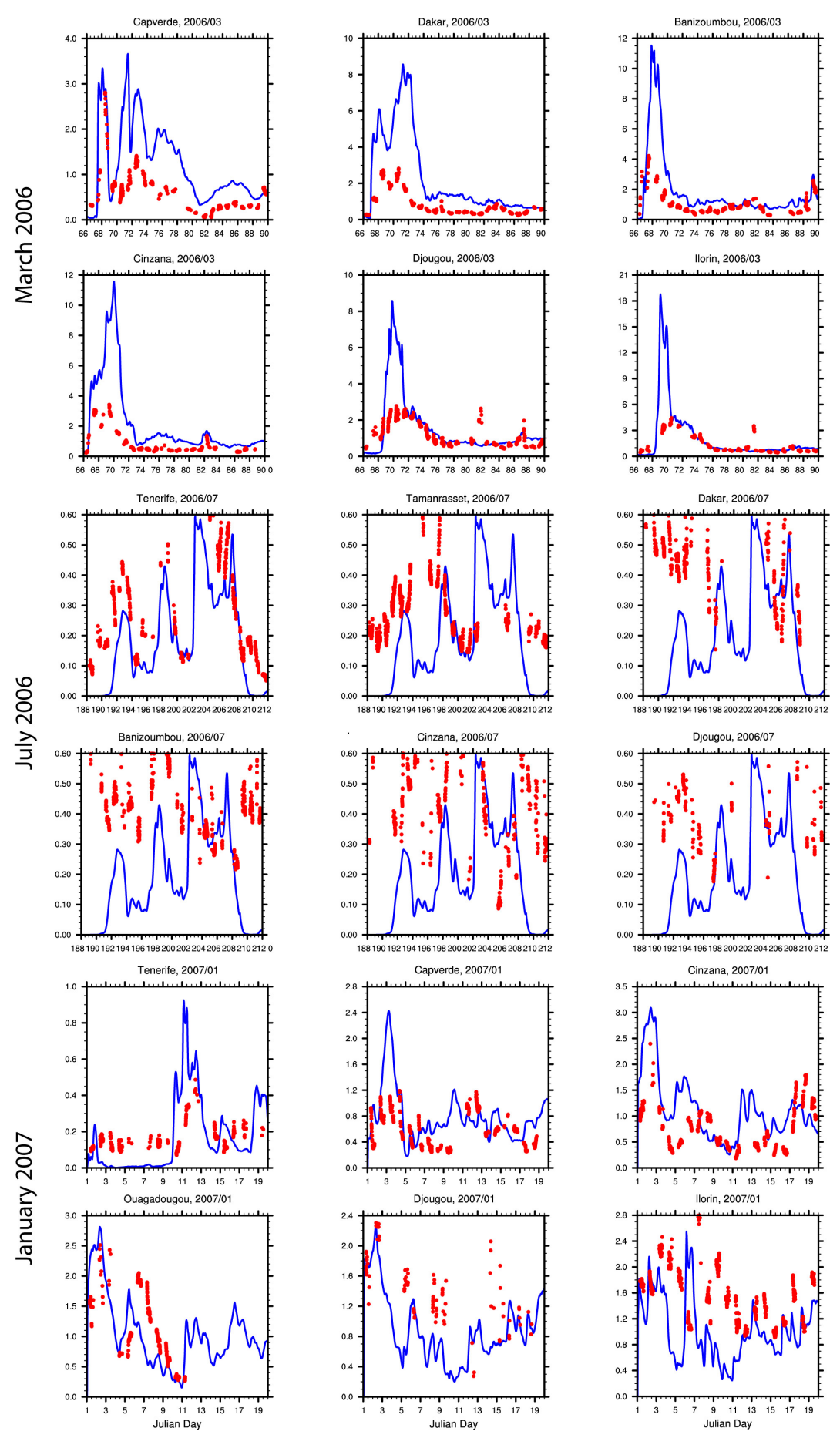

Fig. 5. Comparison of simulated and by sun-photometer observed AOT at North African stations (Santa Cruz de Tenerife $28.5^{\circ} \mathrm{N} 16.3^{\circ} \mathrm{W}$, Tamanrasset $22.8^{\circ} \mathrm{N} 5.5^{\circ} \mathrm{E}$, Cape Verde $16.7^{\circ} \mathrm{N} 22.9^{\circ} \mathrm{W}$, Dakar $14.4^{\circ} \mathrm{N} 17.0^{\circ} \mathrm{W}$, Cinzana $13.3^{\circ} \mathrm{N} 6.0^{\circ} \mathrm{W}$, Banizoumbou $13.5^{\circ} \mathrm{N} 2.7^{\circ} \mathrm{E}$, Ouagadougou $12.2^{\circ} \mathrm{N} 1.4^{\circ} \mathrm{W}$, Djougou $9.8^{\circ} \mathrm{N} 1.6^{\circ} \mathrm{E}$, Ilorin $8.3^{\circ} \mathrm{N} 4.3^{\circ} \mathrm{E}$ ) situated in different transport directions of upwind dust source areas for March 2006 (top two rows), July 2006 (middle two rows) and January 2007 (lower two rows). The stations are sorted according their geographical location, starting with the northern most station. Red dots represent sun-photometer observations (at $440 \mathrm{~nm}$ ), the blue solid line represents the AOT values computed from the model results (at $550 \mathrm{~nm}$ ). Observations are provided by AERONET, http://aeronet. gsfc.nasa.gov. 

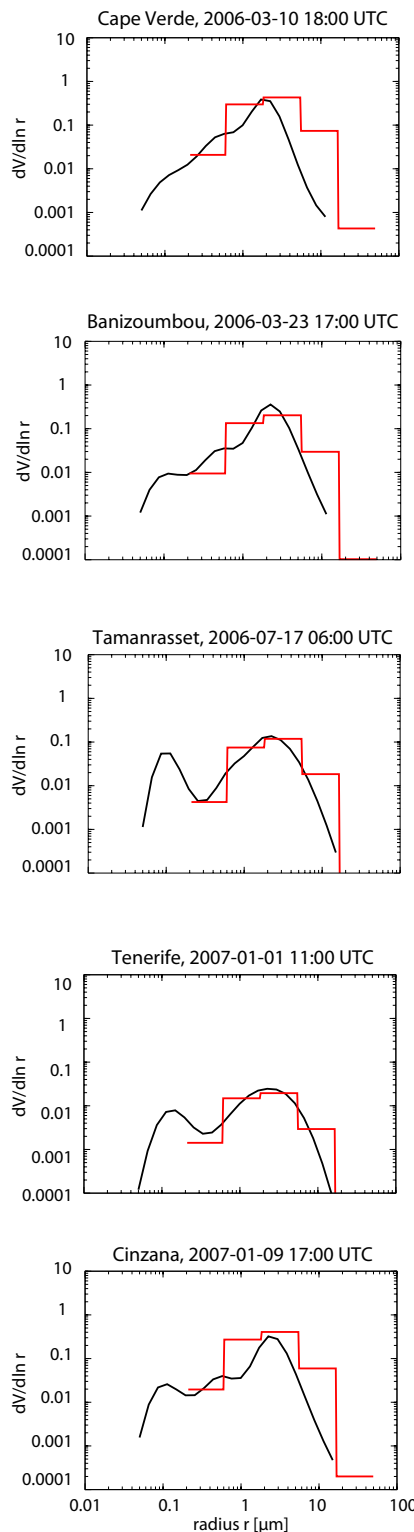
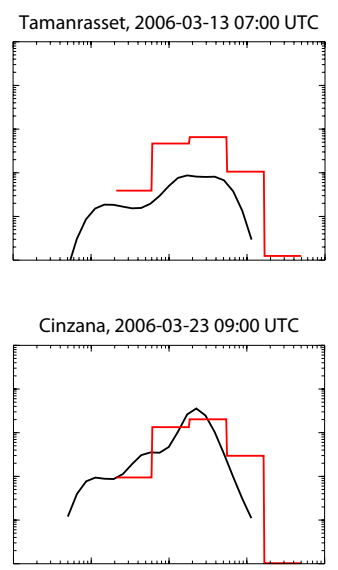

Dakar, 2006-07-18, 17:00 UTC
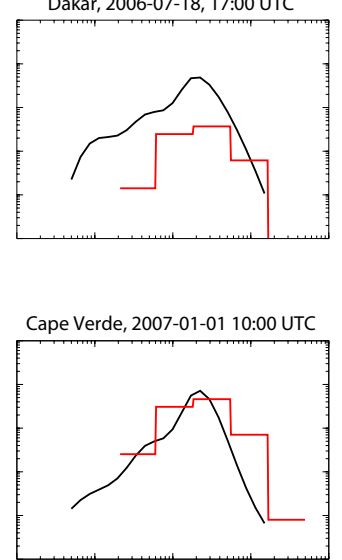

Ouagadougou, 2007-01-10 08:00 UTC

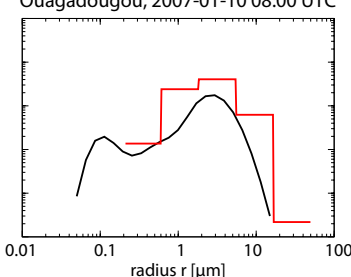

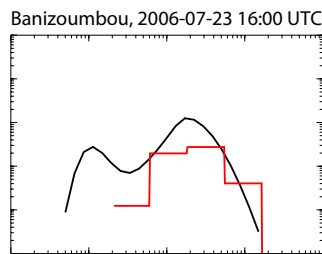
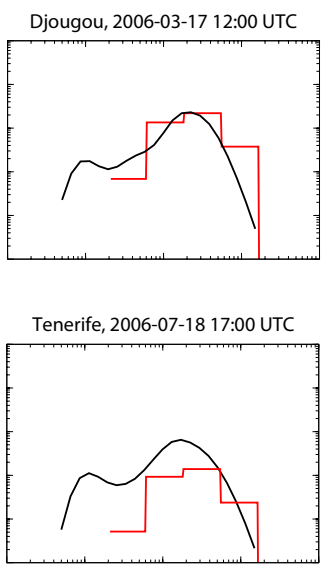

Ilorin, 2007-01-13 08:00 UTC

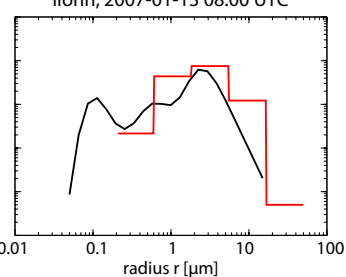

Fig. 6. Comparison of particle size distributions for the model and AERONET observations at stations located in different transport directions regarding upwind dust emission and different distances to the source area (Santa Cruz de Tenerife $28.5^{\circ} \mathrm{N} 16.3^{\circ} \mathrm{W}$, Tamanrasset $22.8^{\circ} \mathrm{N}$ $5.5^{\circ} \mathrm{E}$, Cape Verde $16.7^{\circ} \mathrm{N} 22.9^{\circ} \mathrm{W}$, Dakar $14.4^{\circ} \mathrm{N} 17.0^{\circ} \mathrm{W}$, Cinzana $13.3^{\circ} \mathrm{N} 6.0^{\circ} \mathrm{W}$, Banizoumbou $13.5^{\circ} \mathrm{N} 2.7^{\circ} \mathrm{E}$, Ouagadougou $12.2^{\circ} \mathrm{N}$ $1.4^{\circ} \mathrm{W}$, Djougou $9.8^{\circ} \mathrm{N} 1.6^{\circ} \mathrm{E}$, Ilorin $8.3^{\circ} \mathrm{N} 4.3^{\circ} \mathrm{E}$ ). The upper two rows show chosen distributions in March 2006, the middle two rows for July 2006 and the lower two rows for January 2007. The stations are sorted following their geographical position, starting with the northern most station. Size distribution of the model are given by the red line, those based on sun-photometer observations are given in black.

simulated dust plume (around January 12) arrives about 1-2 days too fast at Tenerife and Cap Verde. The earlier onset is also evident at the Sahelian observation sites Banizoumbou, Cinzana, Ilorin and Ouagadougou. Strong dust events as during 3-5 January at Cape Verde and during 11-13 January at Tenerife are overestimated by the model, whereby the maximum AOT values are well reproduced at Sahelian sites (Ouagadougou, Ilorin, Cinzana, Banizoumbou).
In general, the model is able to capture the seasonal differences of the atmospheric dust cycle comprising emission, transport and deposition in its extent but also in its temporal evolution. For July 2006, difficulties in simulating the observed level of dust concentration are evident.

The AOT as a measure for total dust concentration within the atmospheric column above the reference point does not give any information about the vertical distribution of the 
dust concentration. The regional model LM-MUSCAT provides information about the vertical dust distribution in addition to the column load or AOT. Figure 4 shows the modelled temporal evolution of vertical dust concentration over the Cape Verde at $16^{\circ} \mathrm{N} ; 22^{\circ} \mathrm{W}$ for January 2007, and March and July 2006 representing the characteristics of the different seasons. During winter, the dust transport layer is situated at lower tropospheric levels with maximum dust concentrations up to around $2 \mathrm{~km}$ on most days. Frequently the dust layer extends down to (near-)surface layers (Fig. 4). In summer, the dust transport layer is the Saharan Air Layer (SAL), which is aloft in heights around $4-5 \mathrm{~km}$ and does not extend to the ground levels (see also Sect. 3.1 and Fig. 4c). This vertical layering is also described by Karyampudi et al. (1999). During spring, the dust transport layer can be found in lower tropospheric layers (up to around $2 \mathrm{~km}$ ) as well as in higher levels (around $4 \mathrm{~km}$ height). Dust transport in spring is characterised by a transition from lower (winter) transport heights to high (summer) transport heights (Fig. 4b).

Comparing both, the AOT and vertical dust concentration distributions, it is obvious that high AOT do not necessarily indicate high surface dust concentrations. However, high dust concentrations at surface levels are coincident with high deposition rates. The relation between these three measures are strongly impacted by the height of the dust layer. In winter when the dust layer is situated within the lower troposphere or near the surface within the trade wind layer, high dust deposition rates coincide with high dust concentrations and high AOT values. In summer, this coincidence is not evident due to the dust transport occurring in an elevated layer above the trade winds inversion. However, dust deposition at a specific location is not closely linked to the AOT. Dust deposition depends rather on the vertical distribution of dust concentrations for which the AOT does not take account. However, to retrieve deposition rates from satellite observations, assumptions on the level-height of the dust layer have to be made.

\subsection{Dust size distribution}

Besides the monthly mean of the spatial distribution of AOT over the entire domain (Sect. 3.2) and the validation of the temporal evolution of single dust events at AERONET measurement sites (Sect. 3.4), the comparison of retrieved dust size distribution from sun-photometer measurements (available at http://aeronet.gsfc.nasa.gov) to modelled dust size distributions are a good possibility to validate the integrated effect of emission, transport and deposition processes, which result in the local dust concentration and soil size distribution. To consider the measured particle size distribution of dust aerosol, the criterion $\alpha \leq 0.6$ has to be fulfilled (Dubovik et al., 2002) to select periods with dominant mineral dust fraction. Dust particle size distribution is observed to change with distance from its source due to gravitational settling (e.g. Westphal et al., 1987). As no long-term measurements at active dust source areas are available, the size distribution at emission is still an unknown parameter for most model grid points and has to be estimated from e.g. wind tunnel and field experiments (e.g. Gillette, 1979; Shao et al., 1996). Here, measurements of size distributions at several stations located in the transport field are compared to the modelled size distribution, whereby the stations can be separated into three categories: 1) stations off the coast (Cape Verde and Tenerife), 2) stations in southwestward and westward transport direction like Sahelian stations (Banizoumbou, Cinzana, Ilorin, Ouagadougou, Djougou) and a West African station (Dakar), and 3) a station over the Central Sahara (Tamanrasset). The comparison is shown for typical days of each simulated season to account for seasonal effects impacting on the dust size distribution (Fig. 6).

The observed maximum of the size distribution in the fine mode size range (around $0.1 \mu \mathrm{m}$ ) can be considered as artifact due to the inversion algorithm (Dubovik et al., 2006). In general, the maximum and the shape of the observed size distribution for coarse mode aerosol are in good agreement at most stations at different distances to source areas. The model shows a larger fraction of particles larger than $10 \mu \mathrm{m}$ compared to the AERONET product. Differences in size distributions are evident for stations located in the Central Sahara (Tamanrasset), located in the Sahelian band (Cinzana, Ilorin, Banizoumbou, Ouagadougou), located off the coast (Cape Verde, Tenerife), and located in between (Dakar) (Fig. 6). With increasing transport distance, the distribution becomes narrower, compared to near-source sites.

During summer (July 2006), the observed size distribution is underestimated by the model for stations situated in the transport path, whereby the position of the maxima agree. This is consistent with the too low simulated AOT values over these areas (Fig. 2). Nevertheless, the comparison of model size distribution to observed values shows good agreement although the model size distribution is shifted towards large particles compared to the observed distribution. The general agreement for the different sites and seasons supports the assumption that the model is able to simulate emission, transport and deposition processes realistically.

\subsection{Zonal dust flux}

Besides the horizontal distribution of AOT, dust concentration and dust deposition, zonal dust fluxes can be used to describe dust transport. In case of the Saharan dust export towards the North Atlantic, zonal fluxes can be used to estimate Saharan dust export due to the dominant zonal wind direction in all seasons (e.g. Kaufman et al. (2005)). Here we computed monthly zonal dust fluxes at $10^{\circ} \mathrm{W}, 15^{\circ} \mathrm{W}$ and $20^{\circ} \mathrm{W}$ using the results from the regional dust emission and transport model (Fig. 7). Zonal dust fluxes $F_{\text {dust }}$ are calculated using zonal wind speed $u$ and dust concentration $M_{\text {dust }}$ :

$F_{\text {dust }}=M_{\text {dust }} \cdot u$. 
The $10^{\circ} \mathrm{W}$ meridian crosses the Western Sahara, so the western-most Saharan dust sources will be missed but dust export over the Gulf of Guinea and the Canary Islands will be captured close to the coast. Furthermore, this meridian accounts for atmospheric conditions changing seasonally due to the dominant West African Monsoon circulation in summer and the Harmattan in winter, both impacting strongly on the dust transport path. The $20^{\circ} \mathrm{W}$ meridian is located over the Atlantic and thereby impacted by the marine boundary layer. Both meridional transects start at $2.5^{\circ} \mathrm{N}$ and end at $40^{\circ} \mathrm{N}$, limited by the domain of the regional model LMMUSCAT. The vertical structure of monthly zonal dust export for winter (January 2007) and summer (July 2006) is shown in Fig. 7. In winter, most of the dust is transported within the lower tropospheric layers (up to $2-3 \mathrm{~km}$ height), peaking between $12^{\circ} \mathrm{N}$ and $16^{\circ} \mathrm{N}$ with a maximum westward dust flux of $6 \mathrm{Mg} / \mathrm{m}^{2}$ month. The backward dust transport to the African continent is relatively low with $0.2 \mathrm{Mg} / \mathrm{m}^{2}$ month. Due to dust removal from the atmosphere by deposition and spreading of the dust plume into meridional direction, dust flux at $20^{\circ} \mathrm{W}$ is lower compared to $10^{\circ} \mathrm{W}$. But also at $20^{\circ} \mathrm{W}$ the maximum dust export is located at lower levels and embedded within the trade wind layer. So the maximum of dust export is shifted further northward and peaking at around $17^{\circ} \mathrm{N}$ with a maximum of $4 \mathrm{Mg} / \mathrm{m}^{2}$ month. A backward transport of $0.06 \mathrm{Mg} / \mathrm{m}^{2}$ month occurs over subtropical latitudes and can be explained by the wind fields related to upper-level trough systems.

In summer, a two-layer structure is evident. At levels up to $2 \mathrm{~km}$ height, the southwest monsoon is dominant at latitudes up to $20^{\circ} \mathrm{N}$. The monsoon air is characterised by moist air masses advected from the Gulf of Guinea northward, whereby the Saharan heat low as part of the low pressure trough of the Hadley circulation is a driving factor. As the moist monsoon air is denser than the dry Saharan air mass, the Saharan air including atmospheric dust overlays the monsoon air and thereby it becomes situated above the trade wind inversion at the top of the monsoon air. Thus westward dust export is evident for the elevated layer, which is often termed Saharan Air Layer (SAL). North of the monsoon air, the Saharan air and thereby the dust layer is situated at lower levels, so westward dust export occurs also at levels below $2 \mathrm{~km}$ (Harmattan). Dust sinking downwards from the SAL is enclosed in the trade wind layer and transported back to the African continent. Subtropical dust plumes transported to the Atlantic Ocean might become affected by the anti-cyclonic circulation of the Azores high. The two-layer structure is dominant at $10^{\circ} \mathrm{W}$ due to the strong impact of the WAM, at $20^{\circ} \mathrm{W}$ the SAL transporting Saharan dust over the Atlantic as an elevated layer (maximum at around $4 \mathrm{~km}$ height) above the trade wind inversion is evident.

The Hadley circulation describes the dominant general atmospheric circulation over the North African continent and the adjacent Atlantic Ocean. Due to seasonal solar inclination, the heat trough as part of the circulation changes locally
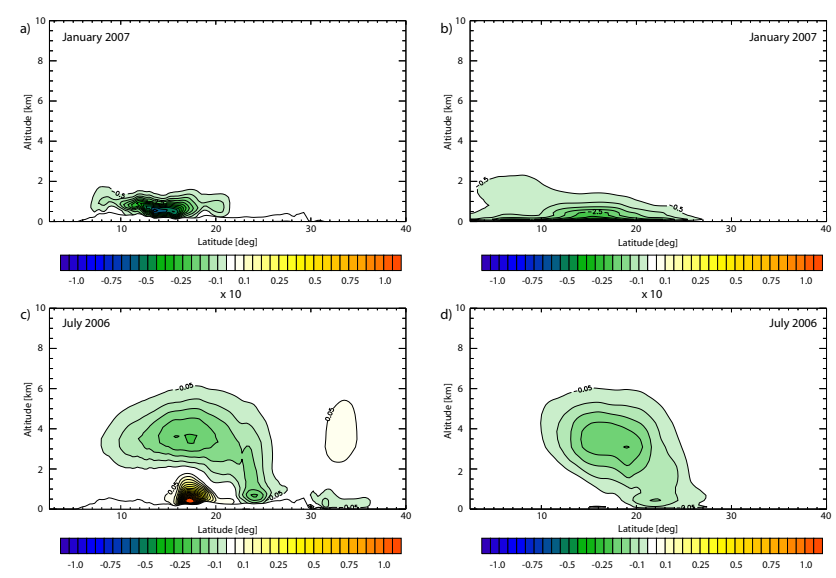

Fig. 7. Vertical distribution of the monthly zonal dust transport $\left[\mathrm{Mg} / \mathrm{m}^{2}\right.$ month $]$ at $10^{\circ} \mathrm{W}$ (a and c) and $20^{\circ} \mathrm{W}$ (b and d) for winter (January 2007) and summer (July 2006). Eastward fluxes are positive, westward fluxes are negative corresponding to the common definition of wind vectors.

and thereby the centrer of the circulation. This explains the dominance of the dust transport at lower tropospheric levels within the northeast trade wind layer, the so called Harmattan. In summer, the southwest trade wind circulation, which causes the monsoon circulation, replaces the Harmattan over at tropical latitudes and forces the elevated SAL. However, the dust export depends strongly on the latitude. Latitudes up to around $25^{\circ} \mathrm{N}$ are dominated by westward dust transport, controlled by the trade wind circulation, and by an eastward dust transport at latitudes north of $25^{\circ} \mathrm{N}$ (Fig. 8). The westward transport is stronger in winter than in summer, which is also affected by lower modelled dust concentrations during summer by LM-MUSCAT. Comparing the eastward (backward) dust transport, in summer higher fluxes occur than in winter. However, beside seasonal changes regarding transport path, the amounts of total column dust fluxes change with the seasons regarding latitude and amount.

\subsection{Bodélé dust}

The Bodélé Depression is the single most active dust source area of the world (e.g. Prospero et al., 2002) and is characterised by a maximum activity in winter and minimum during summer months (Schepanski et al., 2008). The Bodélé, now located in a hyper-arid zone, was a fresh-water lake about 6000 years ago (Lake Mega-Chad,Washington et al., 2003). Today, a hard crust of diatomite covers the former lake floor and provides a large amount of dust by aeolian erosion (Washington et al., 2003). It has been claimed that the diatomite-rich dust originating from the Bodélé Depression has an important fertilising impact on the Amazonian rain forest in South America (e.g. Koren et al., 2006). Here we use the regional model LM-MUSCAT to evaluate the fraction 

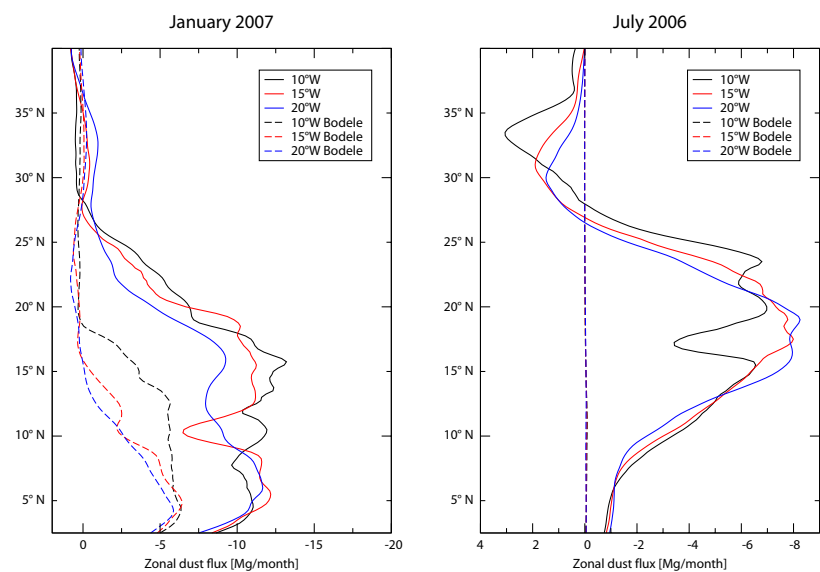

Fig. 8. Zonal dust export $[\mathrm{Mg} / \mathrm{month}]$ as function of the latitude, shown for $10^{\circ} \mathrm{W}$ (black), $15^{\circ} \mathrm{W}$ (red) and $20^{\circ} \mathrm{W}$ (blue). Solid lines represent the zonal dust flux related to dust emissions over the entire model domain, dashed lines only contribute to dust emissions over the Bodélé Depression. Seasonal differences regarding latitude of main dust export and changing transport directions are evident comparing (a) winter and (b) summer.
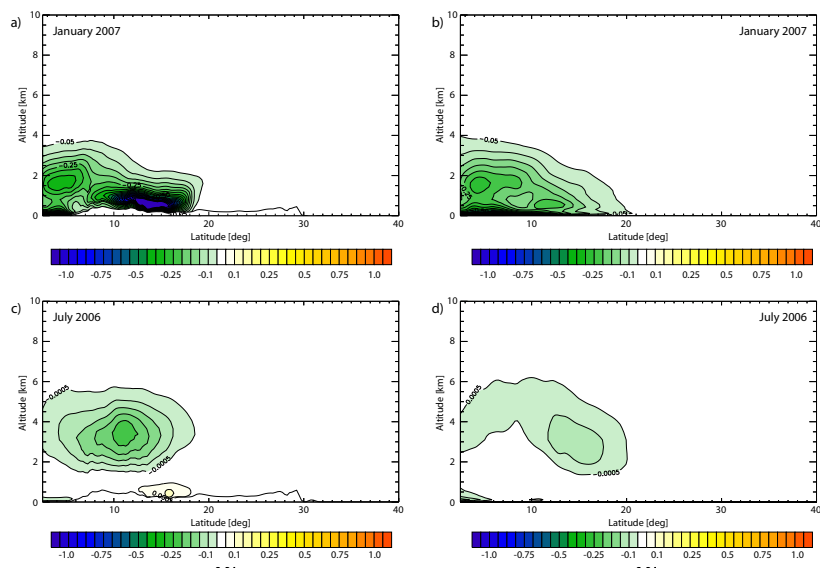

Fig. 9. Vertical distribution of the monthly zonal transport $\left[\mathrm{Mg} / \mathrm{m}^{2}\right.$ month] of dust originating from the Bodélé Depression at $10^{\circ} \mathrm{W}$ (a and c) and $20^{\circ} \mathrm{W}$ (b and d) for winter (January 2007) and summer (July 2006). Eastward fluxes are positive, westward fluxes are negative corresponding to the common definition of wind vectors.

of Bodélé dust over North Africa and the adjacent East Atlantic (Figs. 9 and 10). Due to changing source activity with the seasons, the contribution of Bodéle dust to the total dust load and deposition changes with seasons as well. During winter, the Bodéle Depression is the most active source regarding the number of active days over the entire Sahara and Sahel domain (Schepanski et al., 2008) and consequently the contribution of Bodélé dust is highest during this season. The present modelling study indicates a fraction of dust origi-
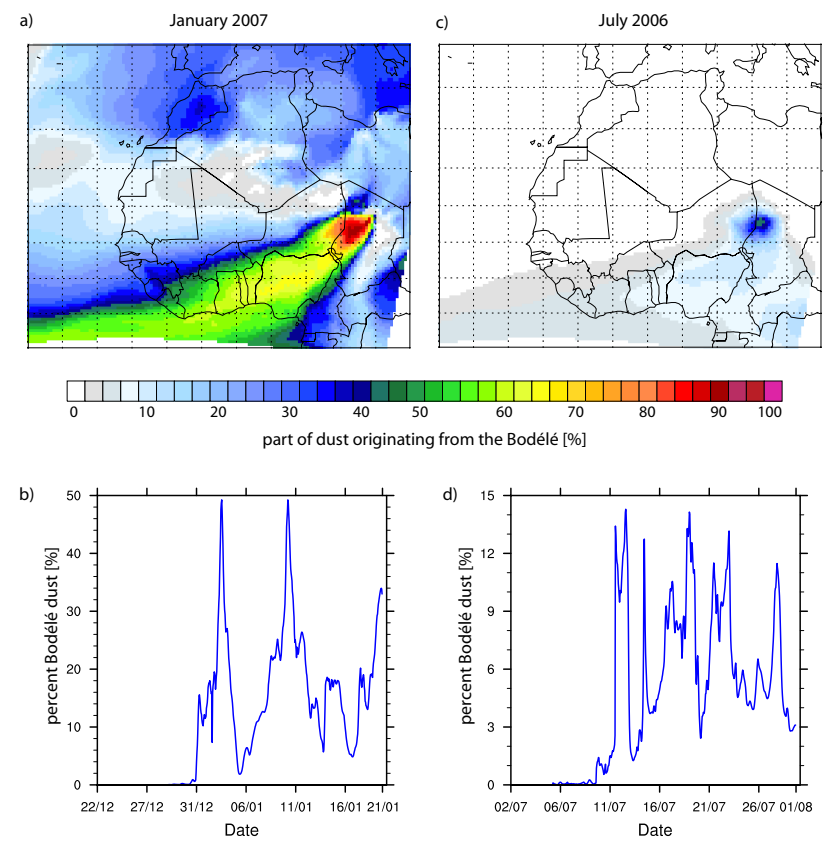

Fig. 10. Percentage of dust concentration originating from the Bodélé Depression source region compared to total dust. (a) and (c) show the horizontal distribution of the contribution of Bodélé, (b) and (d) the part of Bodélé dust over the Cape Verde Islands $\left(16^{\circ} \mathrm{N}\right.$; $22^{\circ} \mathrm{W}$ ). (a) and (b) winter (January 2007), (c) and (d) summer (July 2006).

nating from the Bodélé of up to $50 \%$ over the Cape Verde archipelago. During summer, when the dust source activity in the Bodélé Depression reaches minimum (Washington and Todd, 2005; Schepanski et al., 2008), its contribution to the atmospheric dust content is low (up to $14 \%$ over the Cape Verde Islands). Beside the low source activity in the Bodélé, other source areas show a high activation frequency and are dominant (Schepanski et al., 2008). Over the northern Sahara and the extra-tropical Atlantic, the contribution of dust originating from the Bodélé is significantly lower than over the Sahel and tropical Atlantic.

The zonal flux of dust originating from the Bodélé indicates a strong seasonal dependence to Bodélé dust mobilisation activity and wind regime determining transport direction (Figs. 9 and 8). In winter, maximum dust export from the Bodélé occurs at up to $1.5 \mathrm{~km}$ height within the trade wind layer dominated by the Harmattan winds, peaking at $11-16^{\circ} \mathrm{N}$ with a westward dust export of $-1.4 \mathrm{Mg} / \mathrm{m}^{2}$ month at $10^{\circ} \mathrm{W}$ and $-0.9 \mathrm{Mg} / \mathrm{m}^{2}$ month at $20^{\circ} \mathrm{W}$. In summer, the Bodélé dust export is in eastward direction at levels up to $2 \mathrm{~km}$ height following the southwest monsoon flow. At levels above the southwest monsoon air, dust transport shows a westward direction following the atmospheric circulation as described by the Hadley cell. As the Bodélé is located at around $16^{\circ} \mathrm{N}$ and northward transport of dust from this 
region is not dominant at monthly time scales, the atmospheric contribution of dust originating from the Bodélé is not significant at subtropical latitudes.

The export of dust originating from the Bodélé is significantly lower in summer than in winter (Fig. 8) which can be explained by the significantly lower dust source activity during summer months (Schepanski et al., 2008). However, mineral dust from the Bodélé Depression is able to reach higher tropospheric levels (Fig. 9) which is a precondition for long distance transport as crossing the Atlantic. For transport to South America, two preconditions are fulfilled during winter: wind regimes over the tropical Atlantic have a southwestward component and the Bodélé is most active during this season.

\subsection{Relationship of AOT, dust column load and deposition}

In Sect. 3.6 the dust flux from North Africa towards the tropical and subtropical Atlantic is described using the regional dust emission and transport model LM-MUSCAT. Kaufman et al. (2005) propose a method to determine dust concentrations as well as dust fluxes and dust deposition from space-borne measurements. The authors used AOT based on MODIS observations to derive dust column concentrations assuming a constant ratio between atmospheric column dust load $M_{\text {dust }}$ and AOT $\tau_{\text {dust }}$ :

$$
\frac{M_{\text {dust }}}{\tau_{\text {dust }}}=1.33 \rho_{p} \frac{R_{\text {eff }}}{Q}=2.7 \pm 0.4 \mathrm{~g} / \mathrm{m}^{2},
$$

with the density of dust particle $\rho_{p}$, the effective radius of dust particle $R_{\text {eff }}$ and the light extinction efficiency $Q$. Results from the regional model LM-MUSCAT show a lower $M_{\text {dust }} / \tau_{\text {dust }}$-ratio of $1 \mathrm{~g} / \mathrm{m}^{2}$ (Fig. 11) instead of $2.7 \mathrm{~g} / \mathrm{m}^{2}$ assumed by Kaufman et al. (2005). The model ratio estimated by averaging the ratio over meridional transects. No differences in this ratio pointing towards a seasonal or regional dependence can be found for the three simulated months but the distribution suggests that local errors will occur in using the average relation. Kaufman et al. (2005) derive the AOT from the satellite measured radiance by using look-up tables for fine-mode aerosol $\left(0.1 \mu \mathrm{m} \leq R_{\text {eff }} \leq 0.25 \mu \mathrm{m}\right)$ and coarsemode aerosol $\left(1 \mu \mathrm{m} \leq R_{\text {eff }} \leq 2.5 \mu \mathrm{m}\right)$. Differences for the $M_{\text {dust }} / \tau_{\text {dust }}$-ratio derived from LM-MUSCAT model results using five independent size bins (radius limits at: $0.1 \mu \mathrm{m}$, $0.3 \mu \mathrm{m}, 0.9 \mu \mathrm{m}, 2.6 \mu \mathrm{m}, 8 \mu \mathrm{m}$ and $24 \mu \mathrm{m}$ ) and the ratio proposed by Kaufman et al. (2005) are likely caused by different size distributions of the atmospheric dust load. The size distributions of dust computed by LM-MUSCAT have been compared with near source measurements (Heinold et al., 2009) and AERONET size distributions (Sect. 3.5) as well, yielding good agreement. Differences to earlier cases may be related to differences in the considered atmospheric situation.

Kaufman et al. (2005) determine northern Atlantic dust deposition fluxes by assuming that the gradient of AOT be-
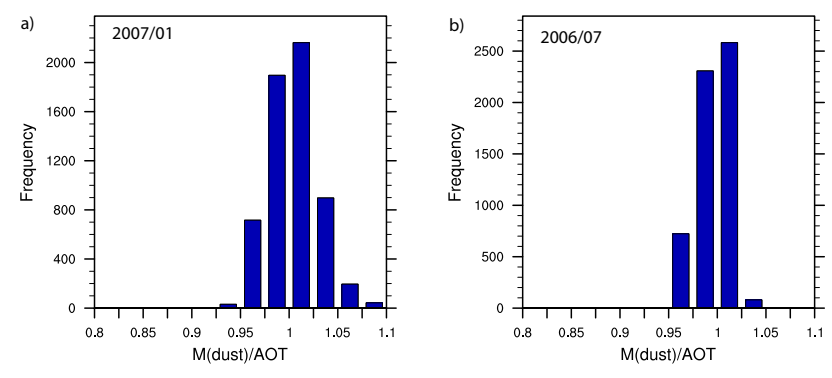

Fig. 11. Frequency distribution of ratio of column dust concentration and AOT for (a) January 2007 and (b) July 2006 following a transect at $16.7^{\circ} \mathrm{N}$ from $30^{\circ} \mathrm{W}$ west of the Cape Verde archipelago to $20^{\circ} \mathrm{E}$ east of the Bodélé Depression.

tween two points is related to the atmospheric removal of dust. To test, whether the derivation of mass fluxes from dust column concentrations based on AOT values is realistic, we compute dust fluxes through a meridional transect over the Atlantic along $15^{\circ} \mathrm{W}$ and $20^{\circ} \mathrm{W}$ using two different approaches: dust flux computed using Eq. (7) at each level (case 1), using Eq. (7) but using total dust column concentration and zonal wind speed at a fixed height $(800 \mathrm{hPa}$ in winter, $700 \mathrm{hPa}$ in summer) (case 2) assuming that the dust layer is contained at this height, so that the dust transport is related to wind speeds occurring at this height. Kaufman et al. (2005) found a high correlations of dust concentrations and wind velocities at this level, motivating this assumption. But the authors also state that this correlations are not evident for seasons and locations (e.g. Cape Verde in winter), when the dust layer is at lower levels. Comparing to dust fluxes computed directly from dust concentrations at each height level, differences concerning the transported dust amount can be found for case 1 and 2 for winter, when the height of maximum dust concentration does not correlate with the assumed wind layer to account for dust transport. For summer, the assumed relation between height of the dust layer and vertical wind distribution is evident, leading to low differences between case 1 and 2. Figure 12 shows the relation between dust deposition rates and changes in zonal dust transport between $15^{\circ} \mathrm{W}$ and $20^{\circ} \mathrm{W}$ for $10^{\circ}$-latitude bands covering the longitudes of main transport region off the North African coast towards the Atlantic. The whole latitudinal region is subdivided as the atmospheric zonal circulation pattern is not similar for each latitudinal band. The atmospheric flow between $10^{\circ} \mathrm{N}-20^{\circ} \mathrm{N}$ is dominated by the WAM circulation in summer (eastward transport within the trade wind layer (up to $2 \mathrm{~km}$ ) and westward transport above the trade wind layer (SAL)) and the Harmattan (westward dust transport within the trade wind layer). The region between $20^{\circ} \mathrm{N}$ and $30^{\circ} \mathrm{N}$ is characterised by the Harmattan leading to a dominant westward air flow. Strong dust outbreaks might also show an eastward transport of dust due to eddy development. Farther 

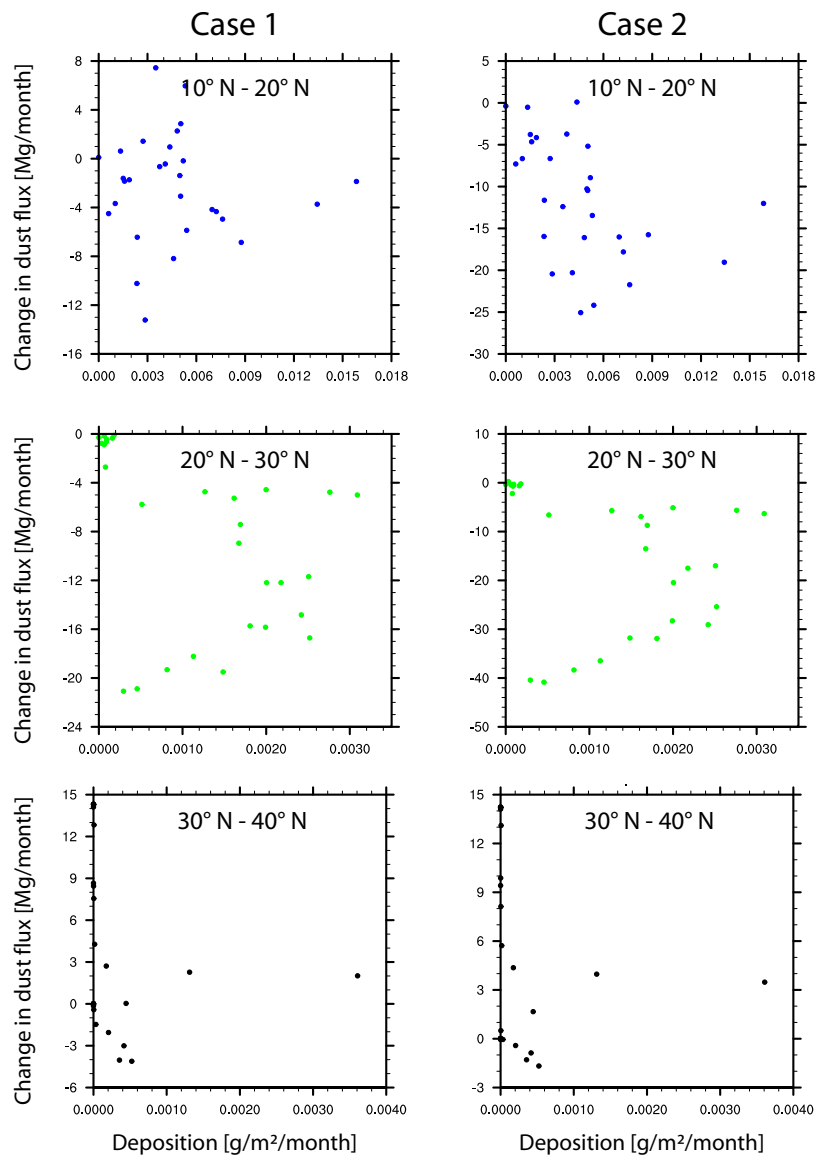

Fig. 12. Scatterplot relating the change of zonal dust flux between $15^{\circ} \mathrm{W}$ and $20^{\circ} \mathrm{W}\left(15^{\circ} \mathrm{W}-20^{\circ} \mathrm{W}\right)$ to the deposition rates for three different latitudinal bands $\left(10-20^{\circ} \mathrm{N}, 20-30^{\circ} \mathrm{N}\right.$ and $\left.30-40^{\circ} \mathrm{N}\right)$ for case 1 and case 2 for July 2006.

north, between $30^{\circ} \mathrm{N}$ and $40^{\circ} \mathrm{N}$, the anticyclonic flow of the Azores high gain influence on the atmospheric circulation. However, the relation of changes in zonal dust fluxes and deposition requires the assumption, that meridional dust fluxes are negligible. Comparing case 1 and case 2 small differences in the pattern are evident for $10^{\circ} \mathrm{N}-20^{\circ} \mathrm{N}$, which are mainly due to the different consideration of the assumption made for the level of transport for case 2. Figure 7 indicates a two layer structure concerning transport direction, representing the impact of the WAM circulation. For case 2, the zonal dust flux is related to winds at a $700 \mathrm{hPa}$ in summer and consequently does not account for the eastward transport within the trade wind layer. At latitudes farther north, the relations between dust deposition and fluxes at the different latitude bands agree for case 1 and case 2 .

For satellite based retrievals of dust fluxes, a correct apriory information on the dust transport height is required. Especially in winter, when transport height might change for individual locations (e.g. over the Cape Verde as shown in
Fig. 4a) height information on sub-monthly time scales are necessary for accurate estimations of the zonal flux. In general, assuming constant heights of dust transport levels leads to good results for seasons and latitudes, but only where a stationary and mono-modal circulation pattern concerning zonal dust flux can be assumed and meridional dust fluxes are negligible.

\section{Conclusions}

The study on Saharan dust export towards the North Atlantic presented here uses results of the regional model system LMMUSCAT to describe seasonal characteristics of horizontal and vertical dust distributions and their evolution exemplary for three case studies each covering a one-month period in different seasons. Transport of Saharan dust is characterised by the vertical and horizontal distribution of atmospheric dust concentrations, dry and wet deposition, and zonal dust fluxes. As airborne dust is an aerosol affected by meteorological features like wind, rain and turbulence changing with seasons, emission, transport, and deposition show seasonal characteristics.

In these case studies, summer and winter are the most dissimilar seasons with regard to Saharan dust transport. In winter, dust concentration has its maximum in near-surface layers over the tropical latitudes. In summer, dust is transported above the trade winds inversion with a maximum westward transport at the lower subtropic latitudes. The vertical distribution of the zonal dust export clearly shows the relation of meridional dust export with general circulation pattern that is mainly controlled by the Hadley circulation.

Considering the dust source activity controlling the atmospheric dust concentration, the Bodélé is most active during winter. Consequently the contribution of Bodélé dust to the Saharan dust load is maximum in winter months. Considering long-range transport as towards the Amazonian rain forest, preconditions are the best during winter months.

As expected, the modelled ratios of AOTs and deposition rates depends strongly on the height of the dust layer. The relation of dust deposition and AOT is evident for dust transported within the near-surface levels dust deposition is directly related to dust deposition, but this is not the case for elevated dust layers. In general, dust deposition rates cannot be derived directly from AOT measurements which agrees with a finding by a comparing modelling/remote-sensing study by Mahowald et al. (2003).

Zonal dust fluxes have been computed using three different approaches by taking the vertical inhomogeneity of the distribution of dust concentration and wind velocity into account. Gradients of dust fluxes between $15^{\circ} \mathrm{W}$ and $20^{\circ} \mathrm{W}$ have been compared to modelled deposition rates pointing towards the role of zonal dust transport especially in case of strong dust plumes, and the transport height. 
Regional models provide a comprehensive data set in horizontal and vertical resolution and are able to capture localscale features. Visual comparisons with the Cloud-Aerosol Lidar and Infrared Pathfinder Satellite Observation instrument (CALIPSO) show promising agreements between modelled vertical distribution of aerosol dust and distributions inferred from attenuated backscatter measurements. A more detailed comparison will be performed in a future study. Model deficiencies of the LM-MUSCAT are evident for July 2006 for which modelled dust optical thickness are too low compared to AOT retrievals and the temporal evolution of dust AOT at some locations was not matched well with AERONET sun-photometer measurements - although at this locations the magnitude of AOT between measurements and model results agree in general. The results for this month indicate a possible overestimation of wet deposition of dust. Too low dust AOT indicates that the modelling of moist convective events which are relevant for dust mobilising processes in this region is deficient. Consequently detailed investigations on dust emission during meteorological summer conditions are required.

Acknowledgements. We thank the Deutscher Wetterdienst (DWD) for good cooperation and support. We also thank D. Tanré, P. Goloub, B. Chatenet, R. T. Pinker, B. Mougenot, O. Hagolle, B. Duchemin, E. Cuevas, J. Cuesta and R. Wagner for his effort in establishing and maintaining AERONET observation sites. The MODIS and OMI satellite data used in this study were acquired using the GES-DISC Interactive Online Visualization ANd aNalysis Infrastructure (Giovanni) as part of the NASA's Goddard Earth Sciences (GES) Data and Information Services Center (DISC). Furthermore, many thanks to the reviewers comments, especially to R. Miller whose comments and suggestions have been a great help to improve the manuscript.

Edited by: Y. Balkanski

\section{References}

Banta, R. M., Pichugina, Y. L., and Brewer, W.: Turbulent VelocityVariance Profiles in the Stable Boundary Layer Generated by a Nocturnal Low-Level Jet, J. Atmos. Sci., 63, 2700-2719, 2006.

Barkan, J., Kutiel, H., Alpert, P., and Kishcha, P.: Synoptics of dust intrusion days from the African continent into the Atlantic Ocean, J. Geophys. Res., 109, D08201, doi:10.1029/ 2003JD004416, 2004.

Berge, E.: Transboundary air pollution in Europe, MSC-W Status Rep. 1997, Part 1 and 2, EMEP/MSC-W Rep. 1/97, Norwegian Meteorol. Inst. Oslo, Norway, 1997.

Blackadar, A. K.: Boundary Layer Wind Maxima and Their Significance for the Growth of Nocturnal Inversion, B. Am. Meteor. Soc., 38, 283-290, 1957.

Chiapello, I., Bergametti, G., Chatenet, B., Bousquet, P., Dulac, F., and Soares, E. S.: Origins of African dust transported over the northeastern tropical Atlantic, J. Geophys. Res., 102, 1370113709, 1997.
Dubovik, O., Holben, B., Eck, T. F., Smirnov, A., Kaufman, Y. J., King, M. D., Tanre, D., and Slutsker, I.: Variability of Absorption and Optical Properties of Key Aerosol Types Observed in Worldwide Locations, J. Atmos. Sci., 59, 590-608, 2002.

Dubovik, O., Sinyuk, A., Lapyonok, T., Holben, B. N., Mihchenko, M., Yang, P., Eck, T. F., volten, H., Munoz, O., Veihelmann, B., van der Zande, W. J., Leon, J.-F., Sorokin, M., and Slutsker, I.: Application of spheroid models to account for aerosol particle nonsphericity in remote sensing of desert dust, J. Geophys. Res., 111, D11208, doi:10.1029/2005JD006619, 2006.

Dunion, J. P. and Velden, C. S.: The Impact of the Saharan Air Layer on Atlantic Tropical Cyclone Activity, B. Am. Meteor. Soc., 85(3), 353-365, 2004.

Eck, T. F., Bhartia, P. K., Hwang, P. H., and Stowe, L. L.: Reflectivity of the Earth's surface and clouds in ultraviolet from satellite observations, J. Geophys. Res., 92, 4287-5296, 1987.

Fung, I., Meyn, S., Tegen, I., Doney, S. C., John, J., and Bishop, J. K. B.: Iron supply and demand in the upper ocean, Global Biogeochem. Cy., 14, 281-296, 2000.

Gao, Y., Kaufman, Y. J., Tanré, D., Kolber, D., and Falkowski, P. G.: Seasonal Distribution of Aeolian Iron Fluxes to the Global Ocean, Geophys. Res. Lett., 28, 29-32, 2001.

Garratt, J. R.: The atmospheric boundary layer, Cambridge University Press, 1992.

Gillette, D. A.: Saharan Dust, chap. Environmental factors affecting dust emission by wind erosion, 71-94, John Wiley, New York, 1979.

Goudie, A. S. and Middleton, N. J.: Saharan dust storms: nature and consequences, Earth-Sci. Rev., 56, 179-204, 2001.

Heinold, B., Helmert, J., Hellmuth, O., Wolke, R., Ansmann, A., Marticorena, B., Laurent, B., and Tegen, I.: Regional Modeling of Saharan Dust Events using LM-MUSCAT: Model Description and Case Studies, J. Geophys. Res., 112, D11204, doi:10.1029/ 2006JD007443, 2007.

Heinold, B., , Tegen, I., Esselborn, M., Kandler, K., Knippertz, P., Müller, D., Schladitz, A., Tesche, M., Weinzierl, B., Ansmann, A., Althausen, D., Laurent, B., Massling, A., Müller, T., Petzhold, A., Schepanski, K., and Wiedensohler, A.: Regional Saharan Dust Modelling during the SAMUM 2006 Campaign, Tellus, 61B, 307-324, doi:10.1111/j.1600-0889.2008.00387.x, 2009.

Herman, J. R., Bhartia, P. K., Torres, O., Hsu, C., Seftor, C., and Celarier, E.: Global distribution of UV-absorbing aerosols from Nimbus 7/TOMS data, J. Geophys. Res., 102, 16922-16922, 1997.

Holben, B. N., Eck, T. F., Slutsker, I., Tanre, D., Buis, J. P., Setzer, A., Vermote, E., Reagan, J. A., Kaufman, Y. J., Nakajima, T., Lavenu, F., Jankowiak, I., and Smirnov, A.: AERONET A Federated Instrument Network and Data Archive for Aerosol Characterization, Remote Sens. Environ., 66, 1-16, 1998.

Hsu, N. C., Tsay, S. C., King, M. D., and Herman, J. R.: Aerosol Properties Over Bright-Reflecting Source Regions, IEEE Trans. Geosci. Remote Sense., 42, 557-569, 2004.

Israelevich, P. L., Levin, Z., Joseph, J. H., and Ganor, E.: Desert aerosol transport in the Mediterranean region as inferred from the TOMS aerosol index, J. Geophys. Res., 107, 4572, doi:10. 1029/2001JD002011, 2002.

Iversen, J. D. and White, B. R.: Saltation threshold on Earth, Mars and Venus, Sedimentology, 29, 111-119, 1982.

Jacobson, H. A., Jonson, J. E., and Berge, E.: The multi-layer Eule- 
rian model: Model description and evaluation of transboundary fluxes of sulphur and nitrogen species for one year, EMEP/MSCW Note 2/97, Norwegian Meteorol. Inst., Oslo, Norway, 1997.

Jickells, T. D., An, Z. S., Andersen, K. K., Baker, A. R., Bergametti, G., Brooks, N., Cao, J. J., Boyd, P. W., Duce, R. A., Hunter, K. A., Kawahata, H., Kubilay, N., LaRoche, J., Liss, P. S., Mahowald, N., Prospero, J. M., Ridgwell, A. J., Tegen, I., and Torres, R.: Global Iron Connections Between Desert Dust, Ocean Biogeochemistry, and Climate, Science, 308, 67-71, 2005.

Journet, E., Desboeufs, K. V., Caquineau, S., and Colin, J.-L.: Mineralogy as a critical factor of dust iron solubility, Geophys. Res. Lett., 35, L07805, doi:10.1029/2007GL031589, 2008.

Kalu, A. E.: The African dust plume: Its characteristics and propagation across west Africa in winter, SCOPE, 14, 95-118, 1979.

Karyampudi, V. M., Palm, S. P., Reagen, J. A., Fang, H., Grant, W. B., Hoff, R. M., Moulin, C., Pierce, H. F., Torres, O., Browell, E. V., and Melfi, S. H.: Validation of the Saharan Dust Plume comceptual Model Using Lidar, Meteosat, and ECMWF Data, B. Am. Meteor. Soc., 80, 1045-1075, 1999.

Kaufman, Y. J., Koren, I., Remer, L. A., Tanré, D., Ginoux, P., and Fan, S.: Dust transport and deposition observed from the Terra-Moderate Resolution Imaging Spectroradiometer (MODIS) spacecraft over the Atlantic Ocean, J. Geophys. Res., 110, D10S12, doi:10.1029/2003JD004436, 2005.

Koren, I., Kaufman, Y., Washington, R., Todd, M. C., Rudich, Y., Martins, J. V., and Rosenfeld, D.: The Bodélé depression: a single spot in the Sahara that provides most of the mineral dust to the Amazon forest, Environ. Res. Lett., 1, 014005, doi: 10.1088/1748-9326/1/1/014005, 2006.

Laurent, B., Heinold, B., Tegen, I., Bouet, C., and Cautenet, G.: Surface wind accuracy for modeling mineral dust emission: Comparing two regional models in a Bodélé case study, Geophys. Res. Lett., 35, L09804, doi:10.1029/2008GL033654, 2008.

Lenschow, D. H. and Stankov, B.: The Rapid Morning BoundaryLayer Transition, J. Atmos. Sci., 36, 2108-2124, 1979.

Luo, C., Mahowald, N., and del Corral, J.: Sensitivity study of meteorological parameters on mineral aerosol mobilization, transport, and distribution, J. Geophys. Res., 108, 4447, doi: 10.1029/2003JD003483, 2003.

Mahowald, N., Bryant, R. G., del Corral, J., and Steinberger, L.: Ephemeral lakes and desert dust sources, Geophys. Res. Lett., 30, 1074, doi:10.1029/2002GL016041, 2003.

Mahowald, N. M., Baker, A. R., Bergametti, G., Brooks, N., Duce, R. A., Jickells, T. D., Kubilay, N., Prospero, J. M., and Tegen, I.: Atmospheric global dust cycle and iron inputs to the ocean, Global Biogeochem. Cy., 19, GB4025, doi:10.1029/ 2004GB002402, 2005.

Marticorena, B. and Bergametti, G.: Modeling the atmospheric dust cycle: 1 . Design of a soil-derived dust emission scheme, J. Geophys. Res., 100, 16415-16430, 1995.

Middleton, N. J. and Goudie, A. S.: Saharan dust: sources and trajectories, Trans. Inst. Br. Geogr., 26, 165-181, 2001.

Moore, C. M., Mills, M. M., Milne, A., Langlois, R., Achterberg, E. P., Lochte, K., Geider, R. J., and Roche, J. L.: Iron limits primary productivity during spring bloom development in the central North Atlantic, Global Change Biology, 12, 626-634, doi: 10.1111/j.1365-2486.2006.01122.x, 2006.

Nappo, C. J.: Sporadic Breakdowns of Stability in the PBL over Simple and Complex Terrain, Bound.-Lay. Meteor., 54, 69-87,
1991.

Neuer, S., Torres-Padrón, M. E., Gelado-Caballero, M. D., Rueda, M. J., Hernández-Brito, J., Davenport, R., and Wefer, G.: Dust deposition pulses to the eastern subtropical North Atlantic gyre: Does ocean's biogeochemistry respond?, Global Biogeochem. Cycles, 18, GB4020, doi:10.1029/2004GB00228, 2004.

Parker, D. J., Burton, R. R., Diongue-Niang, A., Ellis, R. J., Felton, M., Taylor, C. M., Thorncroft, C. D., Bessemoulin, P., and Tompkins, A. M.: Thei diurnal cycle of the West African monsoon circulation, Quart. J. R. Met. Soc., 131, 2839-2860, doi: 10.1256/qj.04.52, 2005.

Prospero, J. M., Ginoux, P., Torres, O., Nicholson, S. E., and Gill, T. E.: Environmental characterization of global sources of atmospheric soil dust identified with the Nimbus 7 Total Ozone Mapping Spectrometer (TOMS) absorbing aerosol product, Rev. Geophys., 40, 1002, doi:10.1029/2000RG000095, 2002.

Reinfried, F., Tegen, I., Heinold, B., Hellmuth, O., Schepanski, K., Cubasch, U., Huebener, H., and Knippertz, P.: Simulations of convectively-driven density currents in the Atlas region using a regional model: Impacts on dust emission and sensitivty to horizontal resolution and convective schemes, J. Geophys. Res., doi:10.1029/2008JD010844, in press, 2008.

Romero, O. E., Lange, C. B., Swap, R., and Wefer, G.: Eoliantransported freshwater diatoms and phytoliths across the equatioral Atlantic: Temporal changes in Saharan dust transport patterns, J. Geophys. Res., 104, 3211-3222, 1999.

Sarthou, G., Baker, A. R., Blain, S., Achterberg, E. P., Boye, M., Bowie, A. R., Croot, P., Laan, P., de Baar, H. J. W., Jickells, T. D., and Worsfold, P. J.: Atmospheric iron deposition and sea-surface dissolved iron concentrations in the eastern Atlantic Ocean, Deep-Sea Research Part I, 50, 1339-1352, doi: 10.1016/S0967-0637(03)00126-2, 2003.

Sarthou, G., Baker, A. R., Kramer, J., Laan, P., Laës, A., Ussher, S., Achterberg, E. P., de Baar, J. H. W., Timmermans, K. R., and Blain, S.: Influence of atmospheric inputs on the iron distribution in the subtropical North-East Atlantic Ocean, Mar. Chem., 104, 186-202, doi:10.106/j.marchem.2006.11.004, 2007.

Schepanski, K., Tegen, I., Laurent, B., Heinold, B., and Macke, A.: A new Saharan dust source activation frequency map derived from MSG-SEVIRI IR-channels, Geophys. Res. Lett., 34, L18803, doi:10.1029/2007GL030168, 2007.

Schepanski, K., Tegen, I., Todd, M. C., Heinold, B., Bönisch, G., Laurent, B., and Macke, A.: Meteorological processes forcing Saharan dust emission inferred from MSG-SEVIRI observations of sub-daily dust source activation and numerical models, J. Geophys. Res., revised, 2008.

Shao, Y., Raupach, M. R., and Leys, J. F.: A model for predicting aeolian sand drift and dust entrainment on scales from paddock to region, Aust. J. Soil Res., 34, 309-342, 1996.

Sinyuk, A., Torres, O., and Dubovik, O.: Combined use of satellite and surface observations to infer the imaginary part of refractive index of Saharan dust, J. Geophys. Res., 30, 1081, doi:10.1029/ 2002GL016189, 2003.

Steppler, J., Doms, G., Schättler, U., Bitzer, H. W., Gassmann, A., Damrath, U., and Gregoric, G.: Meso-gamma scale forecast using the nonhydrostatic model LM, Meteor. Atmos. Phys., 82, 7596, 2003.

Tegen, I., Harrison, S. P., Kohfeld, K., and Prentice, I. C.: Impact of vegetation and preferential source areas on global dust aerosol: 
Results from a model study, J. Geophys. Res., 107, 4576, doi: 10.1029/2001JD000963, 2002.

Tegen, I., Heinold, B., Todd, M., Helmert, J., Washington, R., and Dubovik, O.: Modelling soil dust aerosol in the Bodélé depression during the BoDEx campaign, Atmos. Chem. Phys., 6, 43454359, 2006,

http://www.atmos-chem-phys.net/6/4345/2006/.

Tesche, M., Ansmann, A., Müller, D., Althausen, D., Mattis, I., Heese, B., Freudenthaler, V., Wiegner, M., Esselborn, M., Pisani, G., and Knippertz, P.: Vertical profiling of Saharan dust with Raman lidars and airborne HSRL in southern Morocco during SAMUM, Tellus, 61B(1), 144-164, doi:10.1111/j.1600-0889.2008. 00390.x, 2009.

Tiedtke, M.: A comprehensive mass flux scheme for cumulus parameterisation in large-scale models, Mon. Weather Rev., 117, 1779-1799, 1989.

Torres, O., Bhartia, T. K., Herman, J. R., Sinyuk, A., Ginoux, P., and Holben, B.: A long-term record of aerosol optical depth from TOMS observations and comparison to AERONET measurements, J. Atmos. Sci., 59, 398-413, 2002.

Tsyro, S. and Erdman, L.: Parameterisation of aerosol deposition processes in EMEP MSC-E and MSC-W transport models, EMEP/MSC-W Note 7/00, Norwegian Meteorol. Inst., Oslo, Norway, 2000.

Tulet, P., Mallet, M., Pont, V., Pelon, J., and Boone, A.: The 7-13 March 2006 dust storm over West Africa: Generation, transport, and vertical stratification, J. Geophys. Res., 113, D00D08, doi: 10.1029/2008JD009871, 2008.

Veihelmann, B., Levelt, P. F., Stammes, P., and Veefkind, J. P.: Simulation study of the aerosol information content in OMI spectral reflectance measurements, Atmos. Chem. Phys., 7, 3115-3127, 2007 ,

http://www.atmos-chem-phys.net/7/3115/2007/.
Washington, R. and Todd, M. C.: Atmospheric controls on mineral dust emission from the Bodélé Depression, Chad: The role of the low level jet, Geophys. Res. Lett., 32, L17701, doi:10.1029/ 2005GL023597, 2005.

Washington, R., Todd, M., Middleton, N. J., and Goudie, A. S.: Dust-Storm Source Areas Determined by the Total Ozone Monitoring Spectrometer and Surface Observations, Ann. Assoc. Am. Geogr., 93, 297-313, 2003.

Wedepohl, K. H.: The composition of the continental crust, Geochemica et Cosmochimica Acta, 59, 1217-1232, 1995.

Westphal, D. L., Toon, O. B., and Carlson, T. N.: A TwoDimensional Numerical Investigation of the Dynamics and Microphysics of Saharan Dust Storms, J. Geophys. Res., 92, 30273049, 1987.

Wolke, R., Hellmuth, O., Knoth, O., Schröder, W., Heinrich, B., and Renner, E.: The chemistry-transport modeling system LMMUSCAT: Description and CityDelta applications, in: Air Polution Modeling and Its Aplication XVI, edited by: Borrego, C. and Incecik, S., Proceedings of twenty-sixth NATO/CCMS international technical meeting on air polution modeling and its application, 2004a.

Wolke, R., Hellmuth, O., Knoth, O., Schröder, W., and Renner, E.: The parallel model system LM-MUSCAT for chemistrytransport simulations: Coupling scheme, parallelization and application, Parallel Computing: Software Technology, Algorithms, Architectures, and Applications, 363-370, 2004b.

Zender, C. S. and Newman, D.: Spatial heterogeneity in aeolian erodibility: Uniform, topographic, geomorphic, and hydrologic hypotheses, J. Geophys. Res., 108, 4543, doi:10.1029/ 2002JD003039, 2003. 